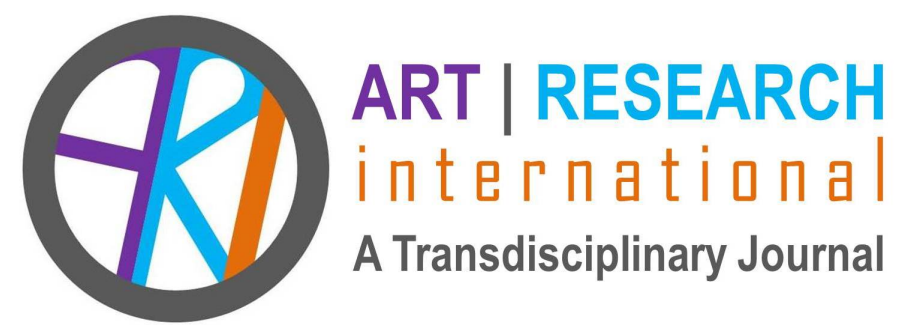

\title{
STAGING THE SHADOW: WRITING, ACADEMIC SUBJECTIVITIES, AND HIDDEN SELVES
}

\author{
John Hoben \\ Faculty of Education \\ Memorial University Newfoundland \\ jhoben@mun.ca \\ Cecile Badenhorst \\ Faculty of Education \\ Memorial University Newfoundland \\ cbadenhorst@mun.ca \\ Sarah Pickett \\ Faculty of Education \\ Memorial University Newfoundland \\ spickett@mun.ca
}

John Hoben, PhD is an Assistant Professor in Memorial University's Faculty of Education. A former practicing lawyer, in 2007 he was awarded a Canada Graduate Scholarship (Doctoral) from the Social Sciences and Humanities Council of Canada to conduct a study of teacher censorship. He is also an award-winning poet who researches how poetry and narrative can be used to provide insights about culture and identity. 
Cecile Badenhorst, $\mathrm{PhD}$ is an Associate Professor in Adult /Post-Secondary Education, Memorial University, Canada. Her interests are doctoral education, thesis/ publication writing pedagogies, academic literacies, and faculty writing. She engages in qualitative, arts-based, and post-structural research methodologies. She has written three books in the area of graduate student writing.

Sarah Pickett, PsyD is an Assistant Professor in the Faculty of Education, Memorial University Newfoundland, Canada and a Registered Psychologist. Her interests are affirmative sexuality and gender practice and pedagogy in education and healthcare. She engages in narrative and autoethnographic research methodologies with a focus on how researchers use these methods to foster evocative conversations in professional and disciplinary contexts.

Abstract: In this paper we explore our writing selves through the metaphors of concealment and display. We discovered the metaphoric possibilities opened up by Jung's notions of persona and shadow and his emphasis on a rich psychic life that was animated by archetypes and symbolic meaning. This process helped us to glimpse alternative selves, that somehow live within us but are, like the shadow, neglected or pushed aside either due to institutional pressures to conceal or due to our own selfconcept and our preferences for displaying certain identity types. Using poetic inquiry to access our unconscious feelings, we engaged in a process of writing that resulted in poetry and poetic vignettes. This type of arts-based practice helped us to disrupt the normative rationalist expectations surrounding academic work and intellectual production, and enabled us to create a space where agency and self-exploration were more accessible and transformative.

Keywords: writing; academic identity; poetry; poetic inquiry; Jungian and post-Jungian perspectives 
Although many scholars have written about the connections between writing and identity, less commonly known are the sometimes unobtrusive ways in which the university conditions identity and makes certain types of self-awareness and expression increasingly difficult, if not impossible (Gill, 2009). Despite the fact that scholars often explore the ways in which they are prohibited from expressing themselves, less obvious are how these institutional spaces filter out certain types of writing identities (Spivak, 1988; Apple \& Buras, 2006). In other words, while academics often think about the types of writing they might be able to engage in if they were freed of institutional constraints, we will explore how the "academy" allows certain types of selves to be created and in turn, how these alternative identities also engender different types of institutional space.

By using poetic inquiry, this article describes a reflexive study that examines parts of our writing identities and how we conceptualize our writing-selves. We ask ourselves: What do we hide in our writing and what do we perform? Over time, much of our writing practice becomes tacit and automatic. Although writing is central to our daily work, it becomes invisible as writing practices become regularised and normalized over time (Paré, 2009). Through long-time use, academic writing genres become so normalized they appear to be "common sense" and universal to old-timers in the system while newcomers experience the specialised and contextually driven nature of disciplinary writing.

What do we hide in our writing and what do we perform? As Starke-Meyerring (2011), remarks, "as genres and writing are allowed to sink into the realm of invisibility and universality, what disappears from our view is the other side of the paradox: the situated, that is, the culturally shaped nature of writing, its deep rootedness in cultural, institutional, and disciplinary traditions of knowledge production" (p. 78). For example, we tell our graduate students to write a literature review as if it were a transparent, neutral task. What we fail to tell them is that writing a literature review requires positioning oneself as a scholar in academic debates, it requires negotiating the discourses and epistemologies of a discipline and it requires a writing identity that is confident enough to be critical of well-established scholars. We engaged in this paper to make visible some aspects of this absent-present that writing plays in our lives. We wanted to explore what we hide and what we display in our writing to become more reflexive within our own institutional settings and more open to the strangeness our students experience in their writing. We used poetry and vignettes because it is one way of accessing our unconscious feelings. This type of arts-based practice helps to disrupt the normative rationalist expectations surrounding academic work and intellectual production, and enables us to create a space where agency and self-exploration are more accessible and transformative. 


\section{Backstory: Theoretical and Personal Frames}

The three of us, all in education, recently created a writing collaboration. We had all known each other for a while, shared similar interests and were drawn together through a common desire to create a writing space that was playful and creative.

Part of the impetus behind our collaboration was also to combat the loneliness of a solitary and often competitive academic environment. We all wanted to work against the grain of this very-encroaching neoliberal model and to gesture towards other ways of living and being in the academy-of engendering a more creative and life-affirming space. We wanted to highlight the complex and invaluable ways in which art can be used to transform otherwise confining and alienating types of formal space; similar to how drama and the arts have been used in all kinds of everyday spaces to disrupt, reimagine, and provoke learners into noticing the world in unexpected ways and engaging their surroundings by taking on multiple perspectives that move beyond the literal, the narrow-minded, and the explicit (Boal, 2002; Eisner, 2002).

As we started working together, however, we also began to recognize the importance of authenticity in our work. But how would one know if one's practice was authentic? How would one know if one's use of theory and methods from progressive or critical pedagogy was nothing more than mere habit? Self-deception became a theme of our discussions, as did the importance of looking at the ways in which the self could be co-opted ideologically to discipline and to filter out more life affirming ways of living. As a result of our conversations about these themes, we began to think about Jung's ideas of persona and shadow (Bolea, 2016; Meredith-Owen, 2011) and how these might help us to look at ourselves askance somehow, to unsettle our "common-sense," and to consider the types of multiple selves that coexist within our own subjectivities and how these multiple identities might not be always be neatly contained and directed by our intentions. We also began to think of methods that would help us dig beneath the surface and challenge us to engage in uncomfortable provocations.

\section{Using Poetic Inquiry}

We turned to poetry and vignettes to explore what we conceal and what we display in our writing. We employed poetic inquiry: a research method where researchers use poetry to learn about selfhood and the world, and to discover the textured, complex and vital nature of human experience (Dobson, 2010; Wiebe \& Snowber, 2011). In the words of one leading scholar in the field, "poetic inquiry is a form of qualitative research in the social sciences that incorporates poetry in some way as a component of an investigation" (Prendergast, 2009, p. xxxv). As a research method, it 
involves both a process of attending to the life poems as well as producing poetic products (Leggo, 2005; 2010). Poetic inquiry demonstrates a unique capacity to express tension, ambiguity and nuance in ways that often work against the grain of conventional notions of academic clarity and precision (Faulkner, 2018). As a tool this method demonstrates a great deal of flexibility and variety. Poetic inquiry can provoke, evoke and unsettle and, as such, it suited our purpose. Our conception of poetry was open ended since we saw the poetic primarily as a mode of expression that was emotive and evocative. This mode of expression relied on imagery and the metaphorical and often drew on cadence and sound to reinforce the impact of its emotive and imaginative intensity. For this reason, we included vignettes as a mode that contained strong poetic as well as narrative aspects. As Prendergast (2009) notes, "poetic inquiry is sometimes presented as a prose-based essay that includes poetry woven throughout" and, she notes, includes forms as varied as "poetic narrative," "poetic texts," "poetic monologue," and "autoethnographic verse" (p. xxxvi). While we had each written and published poetry before, our collaborative venture added layers of depth and skill development. We shared our poetic texts and engaged in an interpretative dialogue which combines the affective and the analytical in unexpected and surprising ways (Gold, 2012). This process of writing, sharing, discussing, reflecting, and rewriting was integral to the poetic method that informed our work.

The interplay between creative poetic expression and explicit analysis was a particularly good fit for our central focus of concealment and display because of the underlying tension between the metaphorical and the rational that gives the reader the freedom to see how each mode of expression might inform - or potentially undercut the other. This notion that we often say less than we intend or that we sometimes disclose meanings that are unknown to ourselves is a central Jungian insight and one that is often edited out from academic discourse.

\section{Persona and Shadow: Using Theory to Move Beyond the Theoretical}

Are we ever fully present to ourselves? This question is at the heart of our commitment to doing work that is authentic, that takes risks, and that can really make a difference to our students. Even though we may recognize that identities are complex and multifaceted, as academics we are often reluctant to accept that emotions and desires are never fully separate from or governed by intentions. These are simple statements with profound implications for teaching and a practice that deals with disclosure and vulnerability, and that aims to transform both self and other.

Consequently, a central focus for our collaboration was Jung's concepts of persona and shadow, concepts that help us to understand what we hide and what we 
display in our writing. We reflected on these aspects of ourselves that make up, knowingly and unknowingly, through self deception or by choice, the rich texture of our lives. We defined the persona as the social face we show the world and the shadow as the unconscious or hidden part of ourselves. For us, Jung's work resonated in powerful ways with the writing of scholars like Ellsworth (1997), Felman (1987), and Britzman (1998) who acknowledge the importance of paradox, tension and contradiction in the practice of teaching and learning. Jung believed that our psychic life was constituted of much more than our intentional conscious thoughts (Jones, 2013). Our fantasy lives are rich sources of psychic energy derived from our connection to a collective unconscious replete with symbolic archetypes - universal archaic patterns which manifest in behaviours - that often echo human myths, poetry and the world of fantasy and dreams. In this sense, our thoughts and desires are not always our own but they are mediated by our unconscious and the world in which we live (McWhinnie, 1985; Laughlin \& Tiberia, 2012).

For Jung, the self was also a product of our interaction with the world. The persona, a mask that the individual puts on in order to achieve recognition, is also only one instance of the self, one that if too closely identified with could disrupt and close off the individuation process. Equally integral to the individuation process is the shadow, a type of alternative possible self, that exists alongside the persona (Meredith-Owen, 2011). We often seek to disavow this shadow self despite the fact that these aspects of our psyche offer the possibility of wisdom through connection with the unconscious and the instinctive world that is often suppressed by social norms and rules (Semetsky \& Delpech-Ramey, 2012). This, then, is why we have chosen to draw on the work of a theorist that seeks to move beyond simple distinctions between inside and outside, conscious and repressed, good and bad, exiled and at-home. As noted by GitzJohansen (2016) Jung's ideas are tools that allow us to encounter what he terms "the Other of education: the unconscious, emotions, personal relations, intuition, imagination, spirituality, meaning, and working with symbols" (p. 379), a countermovement that he sees as necessary to balance a growing tendency towards standardization, quality assurance and rationalization of the curriculum.

Post-Jungian perspectives use postmodern theory and concepts to interpret Jung and to fill in some of the gaps brought by the more foundational and structuralist aspects of his thought (Samuels, 1995; Tougas, 2009). In addition, they have also challenged some of the more patriarchal dimensions of Jungian thought that tend to privilege the masculine ego (Tougas, 2009; Rowland, 2009, 2012). Some have employed approaches from literary criticism and analysis to emphasize the creative aspects of Jung's work and to examine his contribution as being not codified and fixed, but playful, dynamic and in process (Rowland, 2006). This is the sense in which we use Jung. We let his ideas play within the shared spaces of our own personal/professional 
lives to trigger new and unanticipated ways of examining the hidden connections between our personal vulnerabilities and our academic identities.

Although we are not "Jungians" or "post-Jungians" we are intrigued by the resurgence of interest in Jung's work (Gitz-Johansen, 2016) and see his work as offering us a way of entering into another space or mode of being teachers and writers in the academy. This is why we started a process of sharing and disclosure that led us to reveal our fears and insecurities. It opened a portal into this other world that we have been trained to see as inferior or incomplete but that, for this very reason, offers the possibility of renewal for us. Poems and creative vignettes allow us to encounter our writing, not as a conduit for arguments or evidence, but as experiences that carried memories about who we were, what the institution had tried to claim, and how we are shaped in so many different ways. These methods balance the tension between structure and open-endedness so important in allowing us to explore our psychiclandscapes without any preconception of where that travelling should lead or end. Combining emotion, conscious thought and metaphor generated something new. It also provided spaces where concealment and display worked together in counterpoint to make the unexpected happen, and to provide an invitation for others who feel the same fears and trepidations but who still nonetheless find the faith to live and dream.

\section{Staging the Shadow: Individual Poems and Vignettes}

\section{John: Becoming What You Fear}

Loneliness is a familiar experience for me as a new faculty member, although I am not quite sure where the loneliness comes from or where it begins and ends. I also wonder how solitude can become loneliness. Staying engaged can be a challenge when everything seems to be about publication credits and grants. Even if I try to reject this institutional discourse of competition and scarcity it still affects me, perhaps in ways that I do not fully understand. The judgment of this scrupulous peer who is always threatening to tell me that I am not quite good enough, even when I know my work is good, can be subtle and insidious since it is so easily internalized. So an ongoing struggle is to unsettle the way in which we perform the university and the ways the institution insists that we perform ourselves. But we must be careful not to make those choices become a stark either/or since all too often those types of reductive certainties allow us to slip into self-deception.

Whatever its meaning, I do know that I wanted to write a poem about the threat of a judgmental myopic gatekeeper, someone who has ultimately sacrificed so much that they have become lifeless and does not even see how their continued existence 
has become a long continual sneer at all that does not fit with their preconceptions of how the world should be. Of course, I don't think that such a character even knows what they are doing. I suspect that they believe that they are on the side of the right and the good. This is more of an ongoing temptation that we need to face within ourselves, rather than as comfortably projecting the tendency to cast out anything that makes us feel strange or uncomfortable. Likewise, to say that I am not invested in academic culture would be disingenuous: I choose to work and live in an institution that I recognize as being far from perfect, in part because I value the privilege and autonomy that accompanies my position. In other words, although working against the grain is necessary, no one ever said that it was easy or that we wouldn't run the risk of a few splinters.

\section{Reviewer Number 2}

A white man

sits in a room. He is alone

drinking tea by the window,

a napkin folded neatly on his lap;

sun streaming in through the

sullen panes of glass.

He wears a face,

neatly folded

and creased with age

his expression

as inscrutable as the brilliant

clean white of a white table cloth.

Somehow, the china cup holds an

umbrella up for the lukewarm

coffee, that sits renouncing the sun. The single biscuit on his

plate, waits patiently

for the sharp yellowed teeth

the stale rush of breath.

This is the man I fear,

this is the man who will judge me,

he is the harbormaster who looks

intently at the rusted barges and

burly tugs that hurry by the long canal;

He is the magistrate

with cloaked arms peering down,

down, down; 
He is the man who waits for your papers

with open palm and pitiless gaze. He is me,

he is you, he is the white table

that seeks to own, all for its one self

the calm embrace of the

morning sun.

He finishes his biscuit and dabs the cloth

to pursed lips. Off to the tower rising above

manicured grounds, the office

it's walls

lined with many pristine books, a tenure file waiting

obediently on this desk. It bears the epitaph of

poems and lines of poems, that huddle together

like scared cattle

in the heavy dark. Listening for the sound of

an opening door.

The final quickening

wound.

I'm not sure my poem moved me any closer to an answer to the questions I raise above. However, I think that being troubled by them is necessary if we are to live ethically in a world that is often uncaring. Perhaps in some ways the fact that art allows us to embody tensions reminds us that it is often better to live with people who make us feel uncomfortable than to become unkind. Gatekeeping, I think, moves us away from community and towards using power to discipline others rather than trying to care and understand others. This "new" way of writing in an academic setting, writing against its grain, made me feel excited and renewed. To quote Lazarre (1996), it was a reminder that, "each person could appreciate the 'autobiographical attitude' as a pursuit of consciousness through a thicket of false namings; a ritual of self-creation and discovery" (p. 72). According to Jung the shadow can sometimes take on a life of its own, even to the extent that it seems fully differentiated, when we are somehow stuck in our individuation process:

Closer examination of the dark characteristics-that is, the inferiorities constituting the shadow-reveals that they have an emotional nature, a kind of autonomy, and accordingly an obsess or, better, possessive quality. Emotion, incidentially, is not an activity of the individual but something that happens to him. Affects occur usually where adaptation is weakest, and at the same time they reveal the reason for its weakness, namely a certain degree of inferiority and the 
existence of a lower level of personality. On this lower level with its uncontrolled or scarcely controlled emotons one behaves more or less like a primitive, who is not only the passive victim of his affects but also singularly incapable of moral judgment. (Jung \& Campbell, 1976, pp. 145-146)

In the poem, the lines between the imaginary critic and the author are blurred. As Jung (1968) noted, "while some traits peculiar to the shadow can be recognized without too much difficulty as one's own personal qualities, in this case [i.e. of projections] both insight and good will are unavailing because the cause of the emotion appears to lie, beyond all possibility of doubt, in the other person" (p. 146). The critic is seen as lifeless and dispassionate, detached and almost indistinctiable from the institutional furniture that comprise his surroundings. Although the poem articulates the cruelty of institutional judgment, it also hints at the speaker's complicity, since he is anxious about being judged worthy to become part of the institution. The final images in the poem hint at unexpressed feelings, that have an animalistic power and intensity, they are symbols of containment, and perhaps even, industrialized slaughter, hinting at the unspoken psychic forces that are pushed aside by the modern rational mind. Likewise, we also wonder whether these final images of scared domesticated animals and a "final quickening wound" hint at the unacknowledged cost of the writers own complicity. In other words, the distance between persona and shadow are maintained, but the tension between them animates the symbolic power of the poem.

What might we make of knowing with the possibility that, "just as the unconscious affects us, so the increase in our consciousness affects the unconscious"? (McWhinnie, 1985 , p. 99). Rather than seeing this as a problem, we might recognize the futility of a sense of identity that rests on the idea that we can be fully in possession of ourselves. Overcoming loneliness might just mean living with those who make us uncomfortable, since to try and silence or expel them threatens to make us just like them as we model their behaviour. Wounding can be a necessary price to pay for caring and one that often entails living with others even when we are not sure we know how to move forward. In part, I am hopeful because I believe in writing, even when my writing seems filled with doubt and pain. Writing, I believe, is "an active form of meditation that lets us examine our lives and see where and how we can alter them to make them more sound" (Cameron, 1998, p. 232). This process is one that matters much more than lines on a curriculum vitae or lists of publications, it is humanizing and healing, and often, it brings us together, rather than setting us at odds with each other in a mad scramble for prestige.

\section{Sarah: My Sister is the Poet}


If we are teachers who ask our students to be imaginative, to express vulnerability and to find their "voice" as writers then it is important that we, ourselves have integrated these things into our own practice. For me the poetic vignettes that follow represent a turn to language and metaphor to claim a sense of newness and to confess our vulnerability and dissatisfaction with the world--a frustration that, in part, arises from not having a "solution" to a problem that is very much outside of the rational realm. In other words, we turn to language as a way of being, being more fully and authentically, because in the words of John Whitworth (2006), "what is most important about language is not its clarity - though we should try to be as clear as the subject allows - but its invention" (p. 49). We can renew and reinvent ourselves by looking at the murky dark places that we all too often tuck away as if they don't exist, ignoring their power and their secret wisdom, perhaps for far too long. Poems paint pictures, they evoke feelings, they tell stories. For me any question about academic identity brings one irrevocably back to the realm of writing and writing identity - a space that itself is intrinsically lived and personal.

Strangely, perhaps, this exercise made me think about my childhood and my early conceptions of myself that often positioned me outside of the subject role of writers or other creative people. My writing identity is deeply rooted in story. So much that, I can hardly think of a memory of my childhood that is not associated with one of my father's stories, or a significant experience that did not become a story, passed on from generation to generation. My sister's poetry has often transformed my worldview, pierced through me and put to words what I can only grasp conveying, although now her poetry is mostly represented on cards she gave us, cards I've held onto, and a book of my sister's teenage poetry that sits in my step-mother's home. I think of my sister as a writer, a poet, an artist, I am none of these identities and all of them at once, when I tell stories. I think my father must have breathed storytelling into me. He told stories of his folks, of how anger and pride tore a family apart. Through these stories as a young child I was invited into conversations, conversations about politics, history, and relationship negotiations. The stories of my family are complex, with the shadow surfacing from time to time.

Are we racist? We are related to General George Pickett, a confederate leader. No, we are true Americans, after all Francis Pickett was deemed a trader in the Revolutionary war because the English wrote the books. True Americans, isn't that racist? Maybe I'm not racist, because my mother's family is Jewish, I think.

These questions swirled through my elementary and teenage mind and landed me at university seeking answers, through art and psychology. In grade 11, I had been told to give up creative writing and writing in general. The guidance counsellor advised, "your English teacher thinks that conceptually you are strong, your stories are engaging, 
well developed and novel, however, you have problems with the details that distinguish those who enjoy writing from those who should pursue writing. We are advising that you stay in college preparatory English rather than moving on to honours English. Your teacher believes the deficits in your writing are too vast to overcome before university and you should pursue other forms of creative expression. Continue with your dancing, drama and develop your oral presentation skills - play to your strengths. University is competitive Sarah, and you have a real shot at a 'good' school, focus on what's working for you." My father had a grade 12 education. I was the first person in my father's family to graduate university.

Age 16: Note to self. I'm not a writer. Writing will be reserved for personal journals, jotting down ideas, playing around with concepts, a space for formulating oral and artistic stories.

Did I mention that my mother died when I was 12, just before grade 7 to be exact. I missed a lot that year. I was busy constructing a new story of myself, my family, her legacy. I was answering complex questions such as, "who am I without her, who am I because of her, who will I become as a motherless daughter?" My half-sisters mother had died before my parents met. I knew the stories around her death and my parents meeting well. I was not however in grade 7 attending to the details of writing. I was not concerned with how to develop these skills. I had no interest in understanding why it would be more appropriate for me to use a comma than a semi colon. I just wrote. I wrote to understand, to reconcile, to grieve, to give space to stories that I saw unfolding in my family that I wouldn't dare speak, share or name. Now I tell stories, without a writing identity in an institution that expects me to have writing expertise.

My oldest sister is the poet in the family. I remember my father raving about her poetry and her ability to capture experience, nuance, nature, pain and joy at just 17 years of age. He often lamented how she could be widely published if she would have pursued poetry rather than her first husband. I was a flower girl at that wedding, I was 2. My father regularly told a story about that wedding and how I refused to walk down the aisle until all the guests were gone and then proudly walked down throwing my flowers to the empty seats with joy and pride; he'd wonder aloud each time he told the story how I moved from this performance shy young child to a performer in my youth.

What types of identity evoke a sense of belonging and why don't the "personal" aspects of our identities seem to belong within the academy? If this is true, then how can we ever feel at home there, or even, content as "mere persons" in our lives away from institutional spaces? My own writing identity is firmly grounded in the personal and 
relational, qualities that are often pushed to the margins or neglected in academic life a set of affairs that often makes me uncomfortable. By sharing these lived instances and recollections we create new ways of thinking about our shared spaces that are less confining, less dehumanizing and perhaps in this way we can become slowly, gradually, a little freer and more fully present in all of the ways that being embodied vulnerable human beings requires. Like life itself, writing allows us to generate words and images that give form and vitality to these traces and shadowy figures, thereby providing new ways of speaking and learning that are not pre-defined by power structures or even our own desire for the rituals of false closure and the hero/heroine's journey that so often is told and retold in academic life. Jung continually refers to the "numinosity" of symbols and archetypes. These are the language of the individual and the collective unconscious. The image of the happy and carefree flower girl throwing flowers at a wedding has a similar larger-than-life quality. Perhaps she is a symbol of youthful vitality and love that creates new beginnings. In the narrative, the one who cannot write and the one who can, are opposities that are unified by this symbol and by the story itself. Perhaps as Jung (1968) noted this is an example of how "symbols are natural attempts to reconcile and reunite opposites within the psyche" (p. 90). Of course, we will never really know, since as Jung points out, the unconscious speaks through a language of symbols and archetypes that can never be rendered completely conscious. This does not mean however, that they do not speak to us or that they are not evocative. A story can be a living repository of desires, dreams, hopes, and symbols that commemorates a past through a form that is simultaneously an artifact of loss and part of the individual's present identity.

These encounters can be mildly unsettling and may simply give rise to new insights, or they may be part of a process of rebirth, which can be psychically traumatic in many ways (Wittels, 1978). The image of my younger self hints at a public, creative aspect of identity that is linked to connection, generativity and love. My father's narrative of my younger self, is reflected back to me, and it is a performing self, that is reanimated by the act of writing a narrative account. In this sense, the shadow self is the writerly self that my account suggests belongs to my sister. As Jung (1976) emphasizes, "it is the function of consciousness not only to recognize and assimilate the external world through the gateway of the senses, but to translate into visible reality the world within us" (p. 46). My story illustrates how creative writing can disrupt our carefully contained academic identities by evoking and alluding to other ways of living. Rather than being careful, reserved academics who are in control of the process of searching for the answer, the unpredictability of the unconscious life and the ambiguity of symbols, archetypes, dreams and fantasies can be overwhelming. The line between inspiration and possession is one that is often difficult to draw, but it is perhaps one known solely in the act of encountering those aspects of our inner lives, whether that be through 
remembrance, restorying our experiences or through the creative arts - all forms of attending to the world around us.

\section{Cecile: Good Girls and Kitchen Tables}

Sometimes I feel that I have always been an academic. Something in my mother's amniotic fluid shaped me and even though becoming an active bona fide academic was a long time coming, the roots were always there. Like Sarah, I am also a first-generation university graduate, so my academic tendencies did not come from my parents' efforts at socialisation. I think they came from a love for feminism that I developed as a girl growing up in the 1970s. But that feminism has had a shadow side. Pat Thomson, in her article "The Long Goodbye to the Good Girl" (2018) speaks from retirement about her lifelong practice of "doing the right thing" ( $p .243$ ) and how she had to develop strategies to divest herself from "her good girl habits" (p. 244). She shows how the road to the good girl was interwoven with her feminist ideals for women to assume leadership positions and to shoulder positions of strength. Over time, the silent assault of neoliberalism eroded her feminist politics and despite her recognition that she needed to work differently, the pressures to continue being a good girl remained unyielding. "Being good," she suggests, "is an embodied desire to always do what is required-and then some" (p. 248). Then there are the pleasures and rewards in following the good girl path. Satisfaction and enjoyment result from doing well. Pride and competition bolster confidence and self-esteem. The seduction of neoliberalism with its awards, reviews, and continual assessment become entangled in one's own desires. A personal love of reading, writing, and publishing fits well into neoliberal performative agendas (Thomson, 2018). Added to this are the subtle pressures to be "the best academic" that many women feel in the face of individualised and competitive environments. Being a "good girl" is a reasonable coping mechanism under these conditions. Alongside the survival strategies is a "complex process of silencing" of some voices, of women's voices (Boulous Walker, 1998). The costs of survival mount as do the costs of unvoiced resistance. Over the years, my writing has become a method of survival, an example of endurance. What I perform and who I am as a writer are very different things.

\section{Writing at the kitchen table.}

You sit at the kitchen table, a large window to the right. Sunlight washes over you. You watch a little bird, a junco, hopping on a branch in the tree outside the window. Its head turning this way and that, watching warily, keeping an eye out for predators while at the same time looking for nourishment. You will your head away from the junco, the sun and the blue sky, back to the writing that has to be 
done. Today's task is to complete a second round of revisions on a paper you submitted to a peer review journal. Each reviewer has written long, conflicting comments (again) and just reading them makes you heavy, weighted with unvoiced objections. You know, you think, you hope their comments will make the paper better. You sigh as you read that the data analysis is still not clearly explained, despite a blood-sweat-tears page of meticulous justification you created in the last round of revisions. You begin typing, dull, lifeless words. You watch as they plop onto the page and lie there, each isolated from one another, silos without connection. You want the words to hold hands, giggle or perhaps to dance around. But there they sit, unmoving. You wonder if you dropped a junco among the words, if they would scatter, or show some character and be brave. You type "junco" but they sit inactive, inert, looking at you with accusing expressions. You slowly delete "junco." Then you pause, suck in the sun-filled air and breathe deeply. A rebel thought pops into your head: "Don't do the revisions, leave them. Tell the editor-reviewer-crucifiers you are done with this paper. That your body is no longer available for pin-sticking. You begin to feel lighter, a spurt of energy surges through your body. "Yes!" you think, "Yes, I don't have to do this. I can just let it go." Then your eye catches the words on the page. They are no longer lying indolently instead they have snapped into a military formation aimed at you. "Soldier," they yell, "shape up! There's no giving up. Think of that line on your CV. Can you afford to lose your promotion, your pay increase, your pension?" You feel time squeezing closed, compressing with dizzying speed, each tick-tock growing with menace. With each swing of the pendulum, you grow smaller until you have to stretch to reach up and type. The junco hops on to another branch and begins to clean itself. You don't see because you are focused on typing.

What's hidden in my writing

are creatures of fantasy

who burrow under paper

and hide

from the rules and policies I impose.

When I unlock the prison lines

with colour keys,

they gorge themselves

plush with pigment

becoming eyes, and voices

with skies and say-so's

connecting imaginary

to the fiction of my texts. 
Sometimes with my academic writing there is a fight to hold my head above the water. In this state, to infuse the poetic into writing when you are drowning becomes something of an imperative, a buoy to hang hope onto, an optimism that as you lay the sentences down, they will leisurely fly away. Poetic practices have political possibilities to push back the neoliberal wave (Burford, 2018) and, ultimately, to voice some resistance. In my piece, my reaction to the peer review process leads to an unexpected encounter with a junco, a symbol of the unpredictable nature of human curiosity that can give life, renewed vitality, and regeneration. The bird lends a sense of being irreverent, curious, and even unruly as it pecks and hops about, perhaps in the same way that we, as creative writers, need to flit about the innumerable boundaries that constrain our institutional lives. In many ways we are reminded of Jung's comments about the nature of intuition:

Intuition is an unconscious process in that its result is the irruption into consciousness of an unconscious content, a sudden idea or 'hunch'. It resembles a process of perception, but unlike the conscious activity of the senses in introspection the perception is unconscious. That is why we speak of intuition as an 'instinctive' act of comprehension. It is a process analogous to instinct, with the difference that whereas instinct is a purposive impulse to carry out some highly complicated action, intuition is the unconscious, purposive apprehension of a highly complicated situation. (Jung \& Campbell, 1976, p. 51)

The junco represents a different type of insistence than the deliberate determination of the academic speaker, head bent in devotion to another seemingly endless task; it is the insistence of those parts of the psyche that prompts us to return to a more complete form of individuation and life-affirming experience. Can we really find ourselves in moments of interruption? Perhaps it is when we forget ourselves that we are fully open to encounters with otherness and that we are able to attend to the voices of our unconscious, voices that are not simply repressed or ignored as much as flitting from place to place in our lives until we are ready to have an encounter with those hidden aspects of ourselves. The strangeness of these encounters, their suddenness and unexpectedness can be invigorating but they can also be unsettling if we hold too tightly on the need to control or direct our conscious thoughts. The internal censor that often threatens to hinder our creativity is perhaps the opposite of this force, or these imaginings and intuitions. But in the academy so much of our work life is premised on knowing exactly what we are about and going about it better than anyone else. Such a counter-principle, symbolized here by a flitting curious and unhindered bird, would require a totally different space, and totally different professional identities for those who inhabit these spaces. This perhaps is what the shadow, here in the form of a junco can teach us, however we react, one thing is clear, the shadow cannot be contained, 
although we, or perhaps our personas, can rest here unhappy and unfulfilled alone and bewildered if that is the price that we believe is required for "success."

\section{Performing Display and Concealment: Insights}

Why was this process important for us? All of these pieces in some way relate to how we, as academics, hide the creative writing impulse and how that impulse inevitably finds ways of weaving itself back into our writing lives. Quite often this impulse takes on the form of a simple invitation to the world - or the self - and extends through experience to other ways of living or seeing. These alternative identities - the shadow often seem as if they exist side by side with our academic selves - the persona - but really they are closer to us than we often realize. For ultimately they are kept at a distance by our own unwillingness to give ourselves permission to take on more fulfilling and fluid subject roles. For John, his poem expresses a deeply held resentment and fear at institutional hierarchies that edit out our capacity for artistic expression even as he realizes that he is slowly taking on this role at the cost, perhaps of suffocating those aspects of his own selfhood. For Sarah, concealment comes in the form of self-doubt about whether or not she really is a writer, even as she writes eloquently about these feelings and her early experiences with artistic expression. Cecile writes about what it means to be a "good girl" and how these social roles often are a source of selfdiscipline. She feels frustrated with the peer review process and a simple encounter with a junco that reminds her of the powerful transformative possibilities that reside in creative expression once we allow ourselves to remain open to this realm of experience.

Fear of failure and an over-emphasis on the rational can close off creativity, as well as those hidden and unknown sides of ourselves. Identities that are viewed negatively in one context can be powerful and transformative in another. In the academic world, for too long we have insisted on neglecting the affective, the imaginative, and the unstructured worlds of play, love, and desire. In our dialogical process and through our poems and vignettes, we recounted experiences where our shadow selves were revealed by chance encounters that seemed almost random, unexpected, or even startling. This was in marked contrast to our academic personas that constantly seek to plan and order our lives. The experiences of creating poetry and poetic narratives were invigorating and liberating, and opened up new transformative possibilities for writing, feeling and learning. We believe that creativity is closely tied to a willingness to try on new modes of experiencing and feeling everyday life and questioning the powerful institutional conventions that often try to prescribe those types of good and bad selves that frequently take the place of formal rules and prescriptions thereby giving the illusion of freedom. Poetic inquiry and our intense collaborative 
process allowed us to examine institutions through the self, thereby opening up new possibilities for re-imagined forms of work, creativity and play.

Much of what is valuable in Jung for us is metaphorical, and it represents a shift in attending to the world that is necessary to see the newness and richness - the imaginative possibility that inheres in each of us. Connections to writing and teaching relate to this opening oneself up to being otherwise, and in being open to experiences of unsettling that are often also transformative and profound. In the words of Jane Lazarre (1996), reflecting on teaching and writing after a transformational experience, "teaching, like writing, creates a space outside ordinary space, and time outside ordinary time, so that for a finite number of hours, focus and concentration (with the hope of new insight) can become extraordinary as well" (p. 71).

Our efforts at staging the shadow - what is hidden in our writing - helped us to understand the importance of experiencing vulnerability in order to develop a more authentic teaching practice. We began to understand that self-disclosure is not simply a matter of letting one's guard down since, in many cases, we ourselves have not fully worked through the depth of our own feelings and the many different aspects of our identities. Although this matters in all types of teaching, it is especially important for teaching that involves creative writing or that uses literacy practices to evoke emotion and to create stronger connections with students. We have begun to see that it is incredibly important for us, as teachers to engage in the type of risk-taking and putting oneself out there that we continually encourage in our students. This helps not only to develop empathy, but the experience of vulnerability is much richer and more compelling than exploring vulnerability in the abstract. Touching this conflict is not simply an affective experience, it is also, as Deborah Britzman (1998) so eloquently reminds us, a form of knowledge in a world where "education conducts itself as if the separation of good and bad were not a dilemma for the learner and the teacher and if stories and their conflicts somehow end on the last page and do not reach elsewhere" (p. 133).

Although this lack of self-possession, might seem unsettling, it also opens up immense possibilities for self-transformation. It means that listening carefully both to ourselves and others is far more important than we might realize, especially when we are focused on disclosure and healing. Not surprisingly then, all of our pieces touched on themes of belonging and claiming spaces to perform different identities. Sometimes our writing lent a sense of being irreverent, curious and even, unruly as it pecks and flits about, perhaps in the same way that we as creative writers need to flit about the innumerable boundaries and restrictions that constrain our institutional lives. In many ways we are reminded of Jung's comments about the nature of intuition, which is less 
deliberate but somehow more perceptive and creative than our compartmentalizing academic minds.

Our pieces also all describe acts of being judged, and being found wanting. Often these experiences of rejection or diminishment force us to question our sense of self and our place in the world. Yet, writing helps us to move through this sense of loss by assisting us to create new narratives of connection that move us out of isolation and gesture towards new forms of connection. However, this new space is not an "answer"; it might signify a refusal to be content with the simplistic formula built on the foundationalist myth that human thinking and writing should always proceed in a linear, rational fashion from problem to solution, without giving due value to the things we have experienced and felt along the way. The shadow, in this sense, is the stranger among us, and it is one that once disavowed, impoverishes rather than enriches our writing. What the shadow has come to mean to us is not necessarily an object but a mode of recognition that we claim by looking askance and realizing what it is that we have forgotten about ourselves. The fact that this happens at home also reaffirms that the false dichotomy between persona and authentic self, can be retold and re-lived in ways that allow us as writers and academics to live more authentic forms of existence.

Academic life is paradoxical since it involves a type of recognition that is grounded within concealment: thoughtful contemplative reserve is often seen as a virtue even though it may also cordon off connections with other aspects of human identity and experience. Human life consists of much more than the conscious intellect and truly creative and authentic forms of writing require that we remain open to these other aspects of human experience. Even though we are tempted to rationalize this process by pointing out causes and effects, or, even, to the general utility of such an approach, Jung would assure us that this is simply a part of acknowledging the full scope of human experience and psychic existence. Strangely, however, this is not the end of intellectual endeavors but a way of troubling what we think we already know, thereby opening up new pathways of insight and creative impulse--in other words to find new life whose thick roots reach deep down into the interminable dark. 


\section{REFERENCES}

Apple, M., \& Buras, K. (2006). The subaltern speak: Curriculum, power, and educational struggles. New York, NY: Routledge.

Boal, A. (2002). Games for actors and non-actors. London, UK: Routledge.

Bolea, S. (2016). The Persona and the Shadow in Analytic psychology and existentialist philosophy. Philobiblon, 21(1), 84-94.

Boulous Walker, M. (1998). Philosophy and the maternal body. London, UK: Routledge.

Britzman, D. (1998). Lost subjects, contested objects: Toward a psychoanalytic inquiry of learning. Albany, NY: State University of New York Press.

Burford, J. (2018). Sketching possibilities: Poetry and politically-engaged academic practice. Art/Research International: A Transdisciplinary Journal, 3(1), 229-246. DOI: http://dx.doi.org/10.18432/ari29261

Cameron, J. (1998). The right to write: An invitation and initiation into the writing life. New York, NY: Penguin.

Dobson, M.L. (2010). The poetics of self-study: Getting to the heart of the matter. LEARNing Landscapes, 4(1), 131-142. Retrieved from https:// www.learninglandscapes.ca/index.php/learnland/article/view/The-Poetics-of-SelfStudy-Getting-to-the-Heart-of-the-Matter

Eisner, E. W. (2002). The Arts and the Creation of Mind. New Haven, CT: Yale University Press.

Ellsworth, E. (1997). Teaching positions: Difference, pedagogy, and the power of address. New York, NY: Columbia University Press.

Faulkner, S., (2018). Poetic inquiry: Poetry as/in/for social research. In P. Leavy (Ed.), Handbook of Arts-Based Research, (pp. 208-230). New York, NY: The Guilford Press.

Felman, S. (1987). Jacques Lacan and the adventure of insight: Psychoanalysis in contemporary culture. Cambridge, MA: Harvard University Press. 
Gill, R. (2009). Breaking the silence: The hidden injuries of neo-liberal academia. In Flood, R. \& Gill, R. (Eds.), Secrecy and Silence in the Research Process: Feminist Reflections. London, UK: Routledge.

Gitz-Johansen, T. (2016). Jung in education: A review of historical and contemporary contributions from analytical psychology to the field of education. Journal of Analytical Psychology, 61(3), 365-384. DOI: http://dx.doi.org.qe2a-proxy.mun.ca/ $\underline{10.1111 / 1468-5922.12249}$

Gold, K. (2012). A space for stories: Revisiting relational poetry as inquiry on everyday practice. Qualitative Social Work, 12(6), 849-857.

Jones, R.A. (2013). Jung's "Psychology with the Psyche" and the Behavioral Sciences. Behavioral Sciences, 3(3), 408-417. DOI:10.3390/bs303040

Jung, C., \& Campbell, J. (1976). The portable Jung (Viking portable library). New York, NY: Penguin Books.

Jung, C. (1968). Man and his symbols. New York, NY: Dell Publishing.

Laughlin, C., \& Tiberia, V. (2012). Archetypes: Toward a Jungian Anthropology of Consciousness. Anthropology of Consciousness, 23(2), 127-157. DOI:10.1111/j.1556-3537.2012.01063.

Lazarre, J. (1996). Beyond the whiteness of whiteness: Memoir of a white mother of black sons. Durham, NC: Duke University Press.

Leggo, C. (2005). Pedagogy of the heart: Ruminations on living poetically. Journal of Educational Thought. 39(2), 175-195.

Leggo, C. (2010). Lifewriting: A poet's cautionary tale. LEARNing Landscapes. 4(1), 67-84. Retrieved from https://www.learninglandscapes.ca/index.php/learnland/ article/view/Lifewriting-A-Poet\%E2\%80\%99s-Cautionary-Tale

Meredith-Owen, W. (2011). Jung's shadow: negation and narcissism of the Self. Journal of Analytical Psychology, 56(5), 674-691. DOI: https://doi-org.qe2a-proxy.mun.cal 10.1111/j.1468-5922.2011.01939. 
McWhinnie, H. (1985). Carl Jung and Heinz Werner and implications for foundational studies in art education and art therapy. The Arts in Psychotherapy, 12, 95-99. DOI: https://doi.org/10.1016/0197-4556(85)90028-0

Paré, A. (2009). What we know about writing and why it matters. Compendium2: Writing, Teaching, and Learning in the University, 2(1). From: https:// ojs.library.dal.ca/C2/article/view/3720/3408

Prendergast, M. (2009). Introduction: The phenomena of poetry in research: "Poem is what?" Poetic Inquiry in Qualitative Social Science Research In M. Prendergast, C. Leggo \& P. Sameshima (Eds.). Poetic Inquiry: Vibrant voices in the social sciences. (pp. xix-xlii). Rotterdam, NL: Sense

Rowland, S. (2006). Jung, the trickster writer, or what literary research can do for the clinician. Journal of Analytical Psychology, 51, 285-299. DOI: http:// dx.doi.org.qe2a-proxy.mun.ca/10.1111/j.0021-8774.2006.00588.x

Rowland, S. (2009). Ghost and self: Jung's paradigm shift and a response to Zinkin, Journal of Analytical Psychology, 54, 697-715. DOI: http://dx.doi.org.qe2aproxy.mun.ca/10.1111/j.1468-5922.2009.01814.x

Rowland, S. (2012). Jung and the soul of education (at the 'crunch'). Educational Philosophy and Theory, 44(1), 6-17. DOI: http://doi.org/10.1111/j. 1469-5812.2010.00639.x.

Samuels, A. (1995). Can the post-Jungians survive? Psychological Perspectives, 31(1), 55-59. https://doi.org/10.1080/00332929508404846

Semetsky, I., \& Delpech-Ramey, J. A. (2012). Jung's Psychology and Deleuze's Philosophy: The Unconscious in Learning. Educational Philosophy and Theory, 44(1), 69-81. DOI: http://dx.doi.org.qe2a-proxy.mun.ca/10.1111/j. 1469-5812.2010.00670.x

Spivak, G. C. (1988). "Can the Subaltern Speak?" In Marxism and the Interpretation of Culture, C. Nelson \& L. Grossberg (Eds.). Chicago, IL: University of Illinois Press.

Starke-Meyerring, D. (2011). The paradox of writing in doctoral education: Student experiences. In L. McAlpine \& C. Amundsen (Eds.), Doctoral education: Research based strategies for doctoral students, supervisors and administrators (pp. 75-95). Dordrecht, NL: Springer.

Thomson, P. (2018) The long goodbye to the 'good girl': An auto-ethnographic 
account. In Y. Taylor \& K. Lahad (Eds.), Feeling academic in the neoliberal university: Feminist flights, fights and failures, (pp. 243-260), Cham, SWI: Palgrave Macmillan.

Tougas, C. (2009). Opposition and postmodernism. Jung Journal, 3(1), 68-77. DOI: 10.1525/jung.2009.3.1.68

Whitworth, J. (2006). Writing poetry. London, UK: A \& C Black.

Wiebe, S., \& Snowber, C. (2011). The visceral imagination: A fertile space for nontextual knowing. Journal of Curriculum Theorizing, 27(2), 101-113. Retrieved from: http://journal.jctonline.org/index.php/jct/article/view/352/110

Wittels, B. (1978). Jung, art therapy, and the psychotic patient. Art Psychotherapy, 5, 115-121. DOI: http://dx.doi.org.qe2a-proxy.mun.cal 10.1016/0090-9092(78)90001-7 


\section{ENDNOTES}

